\title{
Neurological Study of Patients with Systemic Lupus Erythematosus
}

\author{
SAMAR F. MARZOUK, M.Sc.*; ABEER A. SHAHBA, M.D.**; MHAMED O. RABIE, M.D.* and \\ EL-SAYED A. TAG ELDIN, M.D.* \\ The Departments of Neuropsychiatry* and Internal Medicine**, Faculty of Medicine, Tanta University
}

\begin{abstract}
Background: Systemic lupus erythematosus (SLE) is a chronic autoimmune disease of unknown etiology affecting multiple organ systems including the joints, skin, heart, lungs, kidneys and the nervous system.

Aim of Work: Is to study the neurological manifestations in patients with systemic lupus erythematosus attending Tanta University Hospitals over 6 months.

Patients and Methods: Cross sectional study was carried out on 60 patients with SLE diagnosed according to American College of Rheumatology criteria attending Tanta University Hospitals during six months.

Results: Mean age was $46.7 \pm 12.1$. Fifty two patients were females and 8 patients were males. This study found that 43 patients showed neurological manifestations, headache was the most common representing $51.7 \%$ followed by cognitive impairment $46.7 \%$ and cerebrovascular stroke $13 \%$. 6 patients complicated by seizures in whom 3 patients were focal. Focal slowing was the most common EEG abnormalities while white matter hyper intensity lesions were the most common MRI brain abnormalities

Conclusion: Neurological manifestations are frequent in SLE patients. Headache is the most common neurological manifestation followed by cognitive impairment.
\end{abstract}

Key Words: SLE, Neurological manifestations - Headache.

\section{Introduction}

SYSTEMIC lupus erythematosus (SLE) is a chronic autoimmune disease of unknown etiology affecting multiple organ systems including the joints, skin, heart, lungs, kidneys and the nervous system [1]

Neuropsychiatric systemic lupus erythematosus (NPSLE) is a clinical feature of SLE which is characterized by neurological syndromes of the central, peripheral and autonomic nervous system as well as psychiatric disorders [2]. NPSLE syndromes range from diffuse CNS disorders (acute

Correspondence to: Dr. Samar F. Marzouk,

The Department of Neuropsychiatry, Faculty of Medicine, Tanta University confusional state, psychosis and anxiety) to focal CNS syndromes (seizures, cerebrovascular disease and chorea) and peripheral nervous system disorders (polyneuropathies, mononeuropathies, autonomic disorder and plexopathy) [3] .

Seizure is one of the diagnostic criteria for SLE. It can occur around the onset of the disease. In SLE patients; generalized tonic-clonic seizures are most common but simple and complex partial seizures can occur [4] . Patients with SLE are at increased risk of stroke, cerebrovascular disease affects between $2 \%$ and $15 \%$ of patients with SLE. Acute ischemic stroke is the most common form. Headache is rather a common complaint that can be associated with the disease. Most common types of headache are migraine with or without aura, tension headache and idiopathic intracranial hypertension [5]

Chorea is the best documented movement disorder in SLE and has been associated with antiphospholipidantibody. Most frequent cranial neuropathies involves the 8 th, $3 \mathrm{rd}$, 6 th and less common 5 th, 7 th nerves. Optic neuropathy includes inflammatory optic neuritis \& ischemic thrombotic optic neuropathy [6]. SLE patients have mild to moderate degree of cognitive dysfunction with an overall benign course [7]. The cognitive deficits common in SLE include difficulties in the domains of verbal visual-spatial functioning and executive function [8]

\section{Patients and Methods}

This study was conducted in the Neuropsychiatry department and internal medicine department, Tanta University Hospitals on sixty patients with SLE over six months starting from February 2017. All Patients were above 18 years old with systemic lupus erythematosus diagnosed according to the American College of Rheumatology Criteria, Each patient was subjected to full history taking, full 
neurological examination including assessment of cognitive function using the Montereal Cognitive Assessment scale (MoCA) [9] . Patients with cerebrovascular stroke were assessed by Modified Rankin Disability Scale [10]. Also SLEDAI score was done to all patients. Routine lab investigations were done for all patients including complete blood picture, international normalized ratio, liver \& renal functions and lipid profile, in addition to further lab investigations, including ESR, ANA and Anti-dsDNA. MRI brain were done to all patients with cerebrovascular stroke, headache and cognitively impaired individuals. Cerebral MRV was ordered for only two patients as their MRI brain revealed hemorrhagic infarction and delta signs MRI cervical spine was done to only one patient presented by myelopathy. EEG was done for all patients. Nerve conduction and Electromyography studies for both upper and lower limbs were indicated if there was a possibility of neuropathy or myopathy.

\section{Results}

The total number of cases was 60 patients with mean age $46.7+12.1$ ranging from $22-68$ years with female sex predominance representing $86.7 \%$ in comparison to male $13.3 \%$. The most common educational level was high education which was representing $38.3 \%$ followed by preparatory $20 \%$, secondary $18.3 \%$, primary $16.7 \%$ and illiterate $6.7 \%$. The mean disease duration was $5.10 \pm 4.26$ ranging from 1-6 years (Table 1).

Table (1): Socio-demographic characteristics of the studied patients.

\begin{tabular}{|c|c|c|}
\hline Demographic data & \multicolumn{2}{|c|}{$\begin{array}{c}\text { Number of cases } \\
(\text { No. }=60)\end{array}$} \\
\hline \multicolumn{3}{|l|}{ Age (in years): } \\
\hline Mean $\pm \mathrm{SD}$ & \multicolumn{2}{|c|}{$46.7 \pm 12.1$} \\
\hline \multirow[t]{2}{*}{ Range } & \multicolumn{2}{|c|}{$22-68$} \\
\hline & No. & $\%$ \\
\hline \multicolumn{3}{|l|}{ Sex: } \\
\hline Male & 8 & $(13.3 \%)$ \\
\hline Female & 52 & $(86.7 \%)$ \\
\hline \multicolumn{3}{|l|}{ Educational level: } \\
\hline Illiterate & 4 & $6.7 \%$ \\
\hline Primary & 10 & $16.7 \%$ \\
\hline Preparatory & 12 & $20.0 \%$ \\
\hline Secondary & 11 & $18.3 \%$ \\
\hline High education & 23 & $38.3 \%$ \\
\hline \multicolumn{3}{|c|}{ Disease duration (inyears): } \\
\hline Mean \pm SD & \multicolumn{2}{|c|}{$5.10 \pm 4.26$} \\
\hline Range & \multicolumn{2}{|c|}{$1-16$} \\
\hline
\end{tabular}

The most common educational level is high education representing $38.3 \%$ followed by preparatory $20 \%$,secondary $18.3 \%$, primary $16.7 \%$ and illiterate $6.7 \%$. Fig. (1).

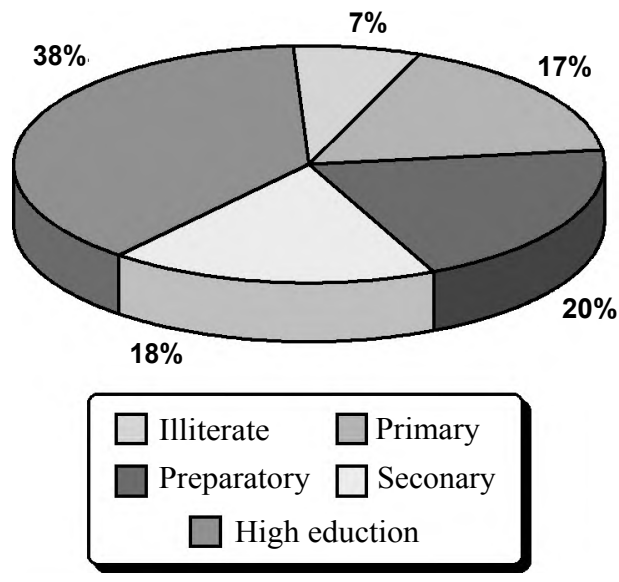

Fig. (1): Educational level of the studied patients.

Photosensitivity was the most common clinical presentations representing $(76 \%)$ followed by neurological $(71.7 \%)$, immunological $(70 \%)$, oral ulcers $(55 \%)$, renal disorder $(50 \%)$, malar rash $(40 \%)$, arthritis (36\%), hematological (31\%), serositis (25\%), discoid rash (3\%). Mean SLEDAI score was $9.92 \pm 6.62$ ranging from 2 to 30 . Table (2).

Table (2): Clinical presentations of SLE according to ACR in the studied patients.

\begin{tabular}{lll}
\hline \multirow{2}{*}{ Clinical presentation } & \multicolumn{2}{c}{$\begin{array}{c}\text { Number of cases } \\
\text { (No.=60) }\end{array}$} \\
\cline { 2 - 3 } & No. & $\%$ \\
\hline Malar rash & 24 & 40 \\
Discoid rash & 2 & 3 \\
Photosensitivity & 46 & 76 \\
Oral ulcers & 33 & 55 \\
Arthritis & 22 & 36 \\
Renal disorder & 30 & 50 \\
Hematological & 19 & 31 \\
Immunological & 42 & 70 \\
Neurological & 43 & 71.7 \\
Serositis & 15 & 25 \\
\hline SLEDAI Score: & \multicolumn{2}{c}{$9.92 \pm 6.62$} \\
$\quad$ Mean \pm SD & \multicolumn{2}{c}{$2-30$} \\
Range & \multicolumn{2}{c}{25} \\
\hline
\end{tabular}

Headache was the most common neurological presentations representing $51.7 \%$ followed by cognitive impairment $46.7 \%$, cerebrovascular $13.3 \%$, seizures $10 \%$, neuropathy $10 \%$ and myelopathy $1.7 \%$. Fig. (2). 


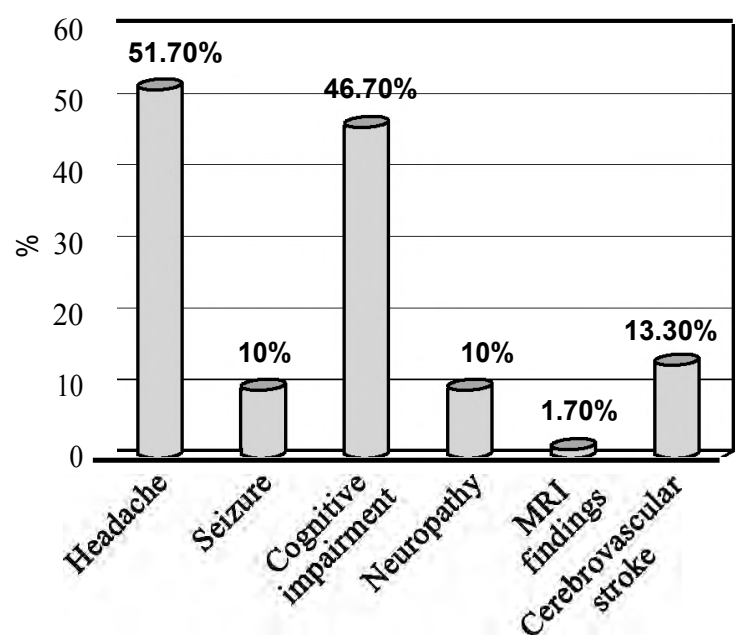

Fig. (2): Neurological presentations of the studied patients.

Migraine with aura was the commonest headache type representing $45.2 \%$ followed by tension headache $25.8 \%$, migraine without aura $22.8 \%$ and headache with unspecified character $6.4 \%$. Table (3).

Table (3): Headache characteristics of the studied patients.

\begin{tabular}{lcc}
\hline \multirow{2}{*}{ Headache character } & \multicolumn{2}{c}{ Number of cases (No.=3 1) } \\
\cline { 2 - 3 } & No. & $\%$ \\
\hline Migraine with aura & 14 & 45.2 \\
Tension headache & 8 & 25.8 \\
Migraine without aura & 7 & 22.6 \\
Unspecified character & 2 & 6.4 \\
\hline
\end{tabular}

There was association between headache and disease duration, hypertension, hematological disorder, cognitive impairment, Cerebrovascular stroke and MRI findings with significant predictor risk factor affecting headache. Table (4).

Table (4): Multivariate regression analysis of factors affecting headache.

\begin{tabular}{|c|c|c|c|}
\hline $\begin{array}{l}\text { Significant predictor } \\
\text { variables }\end{array}$ & $t$ & $\begin{array}{c}p- \\
\text { value }\end{array}$ & $\begin{array}{l}\text { Confidence } \\
\text { interval }\end{array}$ \\
\hline \multicolumn{4}{|l|}{ Demographic data: } \\
\hline Age (years) & 0.73 & 0.43 & $0.20-0.55$ \\
\hline $\operatorname{Sex}$ & 1.001 & 0.28 & $0.013-0.075$ \\
\hline Disease duration & 9.7 & $0.003 *$ & $0.25-0.96$ \\
\hline \multicolumn{4}{|l|}{ Risk factors: } \\
\hline Diabetes mellitus & 2.25 & 0.45 & $0.01-0.86$ \\
\hline Hypertension & 2.43 & $0.001^{*}$ & $0.05-0.93$ \\
\hline \multicolumn{4}{|l|}{ SLE manifestations: } \\
\hline Arthritis & 0.89 & 0.43 & $0.20-0.55$ \\
\hline Renal disorder & 1.001 & 0.28 & $0.013-0.075$ \\
\hline Hematologicaldisorder & 9.7 & $0.023 *$ & $0.25-0.96$ \\
\hline Immunologicaldisorder & 2.25 & 0.45 & $0.01-0.86$ \\
\hline \multicolumn{4}{|l|}{$\begin{array}{l}\text { Neurological presentation } \\
\text { \& radiological finding: }\end{array}$} \\
\hline Seizures & 1.001 & 0.028 & $0.13-0.095$ \\
\hline Cognitive impairment & 9.7 & $0.003 *$ & $0.25-0.96$ \\
\hline Neuropathy & 2.25 & 0.45 & $0.01-0.86$ \\
\hline Cerebrovascular stroke & 2.43 & $0.033^{*}$ & $0.05-0.9$ \\
\hline MRI findings & 10.96 & $0.001^{*}$ & $0.07-0.44$ \\
\hline
\end{tabular}

Focal fits were the commonest type of seizure representing $50 \%$ followed by generalized tonicclonic $33 \%$ and focal with secondary generalization $17 \%$ Table (5).

Table (5): Seizure type among the studied patients.

\begin{tabular}{lcc}
\hline \multirow{2}{*}{ Seizure type } & \multicolumn{2}{c}{$\begin{array}{c}\text { Number of cases } \\
\text { (No.=6) }\end{array}$} \\
\cline { 2 - 3 } & No. & $\%$ \\
\hline Focal & 3 & 50 \\
Generalized tonic-clonic & 2 & 33 \\
Focal with secondary & 1 & 17 \\
$\quad$ generalization & & \\
\hline
\end{tabular}

There was an association between seizures and disease duration, diabetes mellitus, headache, cognitive impairment, cerebrovascular and MRI findings with significant predictor risk factor affecting seizures Table (6).

Table (6): Multivariate regression analysis of factors affecting seizures.

\begin{tabular}{llll}
\hline $\begin{array}{l}\text { Significant predictor } \\
\text { variables }\end{array}$ & \multicolumn{1}{c}{$\begin{array}{c}p \text { - } \\
\text { value }\end{array}$} & $\begin{array}{c}\text { Confidence } \\
\text { interval }\end{array}$ \\
\hline $\begin{array}{l}\text { Demographic data: } \\
\quad \text { Age (years) }\end{array}$ & 0.73 & 0.55 & $0.020-1.55$ \\
$\quad$ Sex & 1.001 & 0.28 & $0.013-0.075$ \\
$\quad$ Disease duration & 9.7 & $0.003^{*}$ & $0.25-0.96$ \\
$\quad$ & & & \\
Riskfactors: & 2.25 & 0.45 & $-0.01-0.86$ \\
$\quad$ Hypertension & 2.43 & $0.001^{*}$ & $0.05-0.93$ \\
$\quad$ Diabetes mellitus & & & \\
& & & \\
SLE manifestations: & 0.89 & 0.43 & $-0.20-0.55$ \\
$\quad$ Arthritis & 1.001 & 0.28 & $.0013-0.075$ \\
$\quad$ Renal disorder & 9.7 & 0.23 & $0.25-1.96$ \\
$\quad$ Hematologicaldisorder & 2.25 & 0.45 & $-0.01-0.86$ \\
Immunologicaldisorder & & & \\
$\quad$ Neurological presentation & & & \\
\& radiological finding: & & & \\
$\quad$ Seizures & 1.001 & $0.028^{*}$ & $0.13-0.095$ \\
$\quad$ Cognitive impairment & 9.7 & $0.003^{*}$ & $0.25-0.96$ \\
$\quad$ Neuropathy & 2.25 & 0.45 & $-0.01-0.86$ \\
$\quad$ Cerebrovascular stroke & 2.43 & $0.033^{*}$ & $0.05-0.9$ \\
$\quad$ MRI findings & 10.96 & $0.001 *$ & $0.007-0.44$ \\
\hline & & & \\
\hline
\end{tabular}

Visuospatial/executive was the commonest domain of cognition that affected in the studied patients $42.9 \%$ followed by Memory $32.1 \%$, Attention $21.2 \%$, Language $17.9 \%$, Naming $10.7 \%$, Abstraction $10.7 \%$, Delayed recall $10.7 \%$ and Orientation $8.3 \%$ Fig. (3). 


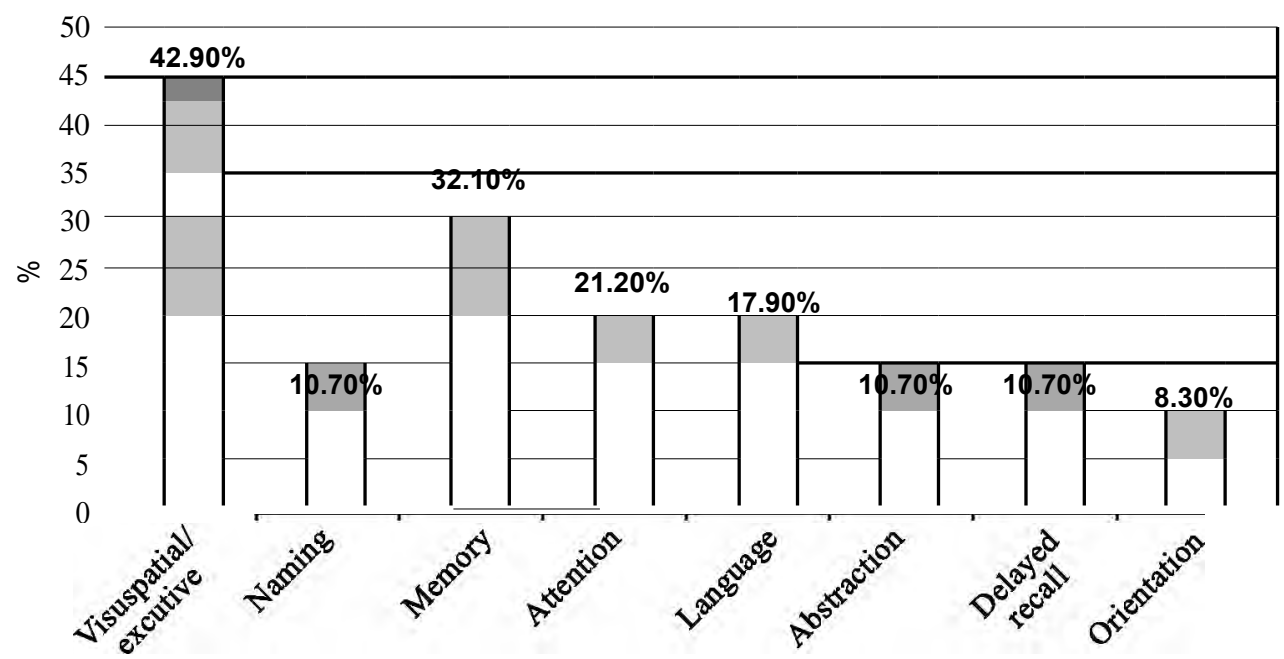

Fig. (3): Affected cognitive Domains among the Studied Patients

Eight patients complicated by cerebrovascular stroke representing $13 \%$ of all patients in whom 2 patients $(25 \%)$ presented by sinus thrombosis and 6 patients $(75 \%)$ presented by arterial ischemic stroke 3 of whom were large and 3 were lacunar. 6 patients $(75 \%)$ presented by side weakness while $2(25 \%)$ patients presented by headache and only 1 patient $(12.5 \%)$ presented by language disturbance. the modified Rankin scale mean was $3 \pm 2$ ranging from 0 to 6 Table (7).

Table (7): Cerebrovascular strokeamong studied patients

\begin{tabular}{|c|c|c|}
\hline \multirow{2}{*}{ Cerebrovascular stroke } & \multicolumn{2}{|c|}{$\begin{array}{c}\text { Number of cases } \\
(\text { No. }=8)\end{array}$} \\
\hline & No. & $\%$ \\
\hline \multicolumn{3}{|l|}{ Type of stroke: } \\
\hline - Sinus thrombosis & 2 & 25 \\
\hline - Ischemic(arterial) & 6 & 75 \\
\hline Lacunar & 3 & 50 \\
\hline Large & 3 & 50 \\
\hline \multicolumn{3}{|l|}{$\begin{array}{l}\text { Clinical picture of } \\
\text { cerebrovascular stroke: }\end{array}$} \\
\hline - Side weakness & 6 & 75 \\
\hline - Language disturbance & 1 & 12.5 \\
\hline - Headache & 2 & 25 \\
\hline \multicolumn{3}{|l|}{ Modified Rankin scale: } \\
\hline Min. - Max. & \multicolumn{2}{|c|}{$0-6$} \\
\hline Mean $\pm \mathrm{SD}$ & \multicolumn{2}{|c|}{$3+2$} \\
\hline
\end{tabular}

There was an association between cerebrovascular stroke and age, disease duration, hypertension, headache,seizure, cognitive impairment and MRI findings with significant predictor risk factor Table $\left({ }^{8}\right)$
Table (8): Multivariate regression analysis of factors affecting cerebrovascular stroke.

\begin{tabular}{|c|c|c|c|}
\hline $\begin{array}{l}\text { Significant predictor } \\
\text { variables }\end{array}$ & $t$ & $\begin{array}{c}p- \\
\text { value }\end{array}$ & $\begin{array}{c}\text { Confidence } \\
\text { interval }\end{array}$ \\
\hline \multicolumn{4}{|l|}{ Demographic data: } \\
\hline Age (years) & 1.31 & $0.043^{*}$ & $0.20-0.55$ \\
\hline Sex & 1.20 & 0.26 & $0.013-0.075$ \\
\hline Disease duration & 9.75 & $0.003 *$ & $0.25-0.96$ \\
\hline \multicolumn{4}{|l|}{ Risk factors: } \\
\hline Hypertension & 2.25 & $0.047 *$ & $0.01-0.56$ \\
\hline Diabetes mellitus & 2.43 & $0.001 *$ & $0.05-0.93$ \\
\hline \multicolumn{4}{|l|}{ SLE Manifestations: } \\
\hline Arthritis & 0.89 & 0.98 & $0.20-1.19$ \\
\hline Renal disorder & 1.05 & 0.25 & $0.013-1.07$ \\
\hline Hematological disorder & 1.32 & 0.33 & $0.25-0.96$ \\
\hline Immunological disorder & 2.95 & 0.85 & $0.01-1.86$ \\
\hline \multicolumn{4}{|l|}{ Neurological presentation } \\
\hline \multicolumn{4}{|l|}{ \& radiological finding: } \\
\hline Headache & 2.65 & $0.045^{*}$ & $0.13-0.095$ \\
\hline Seizure & 9.2 & $0.026^{*}$ & $0.25-0.96$ \\
\hline Neuropathy & 1.25 & 0.45 & $0.01-0.86$ \\
\hline Cognitive impairment & $2 . .32$ & $0.03 *$ & $0.05-0.9$ \\
\hline MRI findings & 11.2 & $0.001 *$ & $0.07-0.44$ \\
\hline
\end{tabular}

EEG was normal in 55\% of patients and $45 \%$ was showing abnormalities. The most common abnormalities was focal slowing representing $28.3 \%$ followed by Generalized spike sharp waves representing $10 \%$, Focal spike sharp waves $8.3 \%$ and Focal spike slow wave with 2ry generalization representing $5 \%$. There was more than one abnormality in many EEG Table (9). 
Table (9): EEG characteristics among the studied patients.

\begin{tabular}{lcc}
\hline & \multicolumn{2}{c}{ Number of cases (No.=60) } \\
\hline EEG eharaeter & No. & $\%$ \\
\hline Normal & 33 & 55.0 \\
Abnormal: & 27 & 45 \\
• Generalized spike sharp waves & 6 & 10.0 \\
• Focal slowing & 17 & 28.3 \\
• Focal spike sharp waves & 5 & 8.3 \\
• Focal spike slow wave with & 3 & 5.0 \\
$\quad$ 2ry generalization & & \\
\hline
\end{tabular}

The MRI brain was abnormal in about 30 patients $(84.4 \%)$ in relation to the normal $16.6 \%$. The most common abnormalities was white matter hyperintensity lesions $47.2 \%$ followed by infarction $19.4 \%$ and cortical atrophy $16.6 \%$ Table (10).

Table (10): MRI findings among the studied patients.

\begin{tabular}{lcc}
\hline & \multicolumn{2}{c}{ Number of cases $(\mathrm{n}=36)$} \\
\hline MRIfindings & No. & $\%$ \\
\hline Normal & 6 & 16.6 \\
Abnormal: & 30 & 84.4 \\
• White matter hyper intensity & 17 & 47.2 \\
- Cortical atrophy & 6 & 16.6 \\
- Infarction & 7 & 19.4 \\
\hline
\end{tabular}

Nerve conduction was done to 6 patients in which 2 patients showed sensorimotor axonal polyneuropathy $(50 \%)$, and 1 patient showed entrapment neuropathy median nerve $(16 \%)$. However, nerve conduction of 2 patients $(33.3 \%)$ was normal Table (11).

Table (11): Neurophysiological study results in the studied patients.

\begin{tabular}{lcc}
\hline Diagnosis & \multicolumn{2}{c}{ Number of cases $(\mathrm{n}=6)$} \\
& No. & $\%$ \\
\hline$N C S:$ & & \\
Sensorimotor axonal polyneuropathy & 3 & 50 \\
Entrapment neuropathy median nerve & 1 & 16.7 \\
Normal & 2 & 33.3 \\
\hline
\end{tabular}

MRI brain was done for 36 patients with different neurological manifestations. MRI brain of 31 patients with headache revealed that 5 patients $(16 \%)$ has normal imaging while 26 patients $(83.8 \%)$ had abnormal findings in comparison to 5 patients without headache whom $20 \%$ had normal imaging and $80 \%$ had abnormal, MRI brain of 28 patients with cognitive impairment showing that only 2 patient has normal imaging while 26 patients
(92.8\%) had abnormal findings also MRI brain of patients with seizures revealed that $33 \%$ had normal imaging while $66.6 \%$ had abnormal imaging. All patients with cerebrovascular stroke had abnormal imaging Table (12).

Table (12): Relation between neurological manifestations and MRI findings.

\begin{tabular}{|c|c|c|}
\hline \multirow{2}{*}{$\begin{array}{l}\text { Presence of neurological } \\
\text { manifestations }\end{array}$} & \multicolumn{2}{|c|}{$(\mathrm{No}=36)$} \\
\hline & Normal MRI & Abnormal MRI \\
\hline \multicolumn{3}{|l|}{ Headache: } \\
\hline Yes $(n=31)$ & $5(16.1 \%)$ & $26(83.8 \%)$ \\
\hline No $(n=5)$ & $1(20 \%)$ & $4(80 \%)$ \\
\hline$X^{2}$ & \multicolumn{2}{|c|}{0.65} \\
\hline$p$ & \multicolumn{2}{|c|}{0.41} \\
\hline \multicolumn{3}{|l|}{ Cognitive impairment: } \\
\hline Yes $(n=28)$ & $2(7.14 \%)$ & $26(92.85 \%)$ \\
\hline No $(n=8)$ & $4(50 \%)$ & $4(50 \%)$ \\
\hline $\mathrm{X}^{2}$ & \multicolumn{2}{|c|}{9.61} \\
\hline$p$ & \multicolumn{2}{|c|}{$0.002^{*}$} \\
\hline \multicolumn{3}{|l|}{ Seizure: } \\
\hline Yes $(n=6)$ & $2(33.3 \%)$ & $4(66.6 \%)$ \\
\hline No $(n=30)$ & $4(13.3 \%)$ & $26(86.6 \%)$ \\
\hline $\mathrm{X}^{2}$ & \multicolumn{2}{|c|}{0.65} \\
\hline$p$ & \multicolumn{2}{|c|}{0.82} \\
\hline \multicolumn{3}{|l|}{ Cerebrovascular Stroke: } \\
\hline Yes $(n=8)$ & $0(0.0 \%)$ & $8(100 \%)$ \\
\hline No $(n=28)$ & $6(21.4 \%)$ & $22(78.5 \%)$ \\
\hline$X^{2}$ & \multicolumn{2}{|c|}{4.04} \\
\hline$p$ & \multicolumn{2}{|c|}{$0.039^{*}$} \\
\hline
\end{tabular}

Table (13): Comparison between symptomatic and asymptomatic patients regarding SLEDAI score among the studied patients.

\begin{tabular}{lcc}
\hline & \multicolumn{2}{c}{ Number of cases $(\mathrm{n}=60)$} \\
\cline { 2 - 3 } & $\begin{array}{c}\text { Symptomatic } \\
(\mathrm{n}=43)\end{array}$ & $\begin{array}{c}\text { Asymptomatic } \\
(\mathrm{n}=17)\end{array}$ \\
\hline $\begin{array}{l}\text { SLEDAI score: } \\
\text { Mean } \pm \text { SD }\end{array}$ & $18.5 \pm 2.6$ & $6.5 \pm 2.3$ \\
Range & $13-30$ & $2-15$ \\
$t$-test $(p$-value $)$ & \multicolumn{2}{c}{$5.9(0.001)^{*}$} \\
\hline
\end{tabular}

There was a significant difference between symptomatic and asymptomatic patient regarding SLEDAI score, $p=0.001$.

\section{Discussion}

In 1999, American college of Rheumatology (ACR) developed the nomenclature and case definitions for the 19 NPSLE syndromes. With respect to validation, these case definitions provided a satisfactory detection rate of $91 \%$ for NPSLE; 
however, the specificity was only $46 \%$. Jeong et al., 2014 [11].

This study found that SLE was more common in female than male with $86.7 \%$ in female and $13.3 \%$ in male. This result is similar to Ainilia et al., [12], in which the prevalence was $84 \%$ in female and is near to the result of Hafez et al., [13]. which was $93 \%$. The mean disease duration of SLE in this study was $5.10 \pm 4.26$ ranging from 1 to 16 years which is similar to Appenzeller et al., [14] in which disease duration mean was $5.54 \pm 4.87$. But this result was inconsistent with the mean disease duration in Sibbitt et al., [15] study in which the mean was $7.82 \pm 6.1$ this difference could be explained by different age group as that study was conducted at pediatric age group.

The most common SLE clinical presentations in this study was cutaneous manifestations in the form of photosensitivity $76 \%$ which is consistent with study Foering et al., [16] in which photosensitivity was representing $81 \%$ however Khedr et al., [17] reported a lower prevalence 33\%. This discrepancy can be explained by disparity in number of patients in each study.

In the current study, the frequency of nervous system involvement was about $71 \%$ which is similar to the reported prevalence in Afeltra et al., [18] study which was $72 \%$ and near to the frequency in the study of Hafez et al.,2007 [13] and Ainilia et al., [12] which was $80 \%$ and $91 \%$ respectively. In contrary to this result the frequency detected by Zhou et al., [19] and Flower et al., [20] was about $12.2 \%$ and $15 \%$ respectively. This variation may be due to different populations and regions (including race, socioeconomic status) and study methodology.

The most frequent neurological manifestations in this study were headache $(51.7 \%)$ cognitive impairment (46.7\%) and cerebrovascular stroke $(13 \%)$. In fact, the frequency of headache in the current study was similar to the prevalence in the general population according to Stovener et al., 2007 [21] study which was 55\%. Also, some researchers believed that headache was frequent in the general population and was usually unrelated to SLE. Wang et al., [22]

In this study 14 patients of 31 patients with headache was complaining of migraine with aura and 8 patients reported tension headache. Migraine without aura was reported in 7 patients with headache while 2 patients were complaining of headache with unspecified character. Disease duration is considered to be a risk factor for headache in this study with significant $p$-value which is consistent with the findings of study Chiewthanakul et al., [23] and inconsistent with Abdel-Sattar et al., [24] in which disease duration was not a risk factor for development of headache in SLE patients.

In the current study cognitive impairment was reported in 28 patients representing $46.7 \%$. Visuospatial/executive functions and memory are the most affected cognitive domains with frequency of $20 \%$ and $15 \%$ of cognitively affected patients This results were near to the reported prevalence of cognitive impairment in study of Alfeltra et al., [18] and Brey et al., [25] which was $52.5 \%$ and $41.4 \%$ respectively but there was a lower prevalence in Mok et al., [26] and Schenatto et al., [27] reaching $3.5 \%$ and $3.4 \%$ respectively. This variation may be due to different methods used for cognitive assessment and also for the educational level of selected patients.

In this study, 8 patients were complicated by cerebrovascular stroke in whom 6 patients presented by arterial ischemic stroke and 2 patients presented by sinus thrombosis but hemorrhagic stroke was not reported in this study. This frequency is consisted with Yu et al., [28] and Sibbitt et al., [15] studies with frequency of $13.5 \%$ and $12 \%$ respectively but there was lower prevalence reported inAbdel Nasser et al., [29] and Brey et al., [25] $3.1 \%$ and 1.6 respectively. The explanation for this discrepancy may be wide variations of number of studied patients and also duration of each study.

In this study, nerve conduction was done only for symptomatic patients in whom 3 patients were complaining of persistent numbness and distal weakness of both hands, their nerve conduction revealed sensorimotor axonal polyneuropathy. One patient was complaining of persistent left hand numbness, nerve conduction revealed left median nerve entrapment neuropathy. Other two patients were complaining of numbness of both hands but their nerve conduction was normal.

This result is near to the reported prevalence of neuropathy in Alfeltra et al., [18] and Brey et al., [25] studies which was $13.1 \%$ and $15.6 \%$ respectively but other studies recorded a higher prevalence for example Ainilia et al., [12] . reported 28\%. But Abdel Nasser et al., [29]. Did not report any case with peripheral neuropathy. This variation may be due to different methodology and number of studied patients and duration of each study.

In this study, EEG was done for all cases. EEG interpretations was showing 55\% patients had 
normal EEG and $45 \%$ had abnormal EEG. This results is similar to Gora et al., [30] in which the abnormal EEG was seen in $49.3 \%$. Other studies reported a higher EEG abnormality for example Kheder et al., [17] and Matsukawa et al., [31] reported $71 \%$ and $90 \%$ respectively. On the other hand, Omdal et al., [32] recorded a prevalence of $33 \%$. This wide variations could be explained by different number of studied patients and methodology.

The most common MRI brain abnormality in this study was white matter changes representing $47.2 \%$ of all abnormalities followed by infarction representing $19.4 \%$ and cortical atrophy $16.6 \%$. Also we found significant association between MRI brain abnormality and cognitive impairment also with cerebrovascular stroke which is consistent with Appenzeller et al., [14] and Ainlia et al., [12] studies that found association between MRI brain abnormalities, cognitive impairment and cerebrovascular disease respectively.

Generalized SLE activity is a major risk factor for SLE related neuropsychiatric events. SLEDAI is a validated model for the overall evaluation of disease activity in SLE patients and can be of great use in treatment. Wang et al., [33]. In this study, SLEDAI score mean was about $18.5 \pm 2.6$ in patients with neurological complications denoting disease activity in comparison to others without any neurological complications. This results are in accordance with previous study Abdel Sattar et al., [24] which found more organ damage in the NPSLE group, which was, as expected, due to neurological disease.

Conclusion: Neurological complications are frequent in SLE patients. Headache, cognitive impairment and cerebrovascular disease are the most common neurological complications. SLEDAI score is high in patients with neurological complications denoting disease activity. Sensorimotor axonal polyneuropathy are the most common type of peripheral neuropathy in SLE. White matter hyperintenesity lesions are the most common MRI brain abnormality in SLE.

\section{Acknowledgments:}

This research was carried out without funding.

\section{Conflicts of interest:}

No conflicts of interest declared.

\section{Authors' Contributions:}

All authors had equal role in design, work, statistical analysis and manuscript writing. All authors have approved the final article work.

\section{References}

1- PONS-ESTEL G.J., ALARCON G.S., SCOFIELD, et al.: unerstanding the epidemiology and progression of systemic lupus erythematosus. Semin Arthritis Rheum., 39: 25768, 2010.

2- BERTSIAS G.K. and BOUMPAST D.T.: Pathogenesis. Diagnosis and management of neuropsychatric systemic lupus erythematosus manifestations . Nat. Rev. Rheumatol., 6: 358-67, 2010.

3- DAVID HERMOSILLO-ROMO and ROBIN L. BREY. Neuropsychatric Involvement in Systemic lupus Erythematosus. Current Rheumatology Report, 4: 337-44, 2002.

4- DEVINSKYO, SCHEIN and NAJJARS: Epilepsy associated with systemic autoimmune disease. Epilepsy Cur., 3: $62-8,2013$

5- ZOUHAYR SOUIRTI, MARIAM LAHLOU, OURDA ELOULI, et al.: " Neuropsychatric Systemic Lupus Erythematosus " open journal of Rheumatology and Autoimmune Disease, 3: 86-91, 2013.

6- G.K. BERTSIAS, J.P.A. LOANNIDIS, ARINGER M., et al.: EULAR Recommendations for the management of systemic lupus erythematosus with neuropsychatric manifestations; report of a task of EULAR standing committee for clinical affairs. Ann. Rheum. Dis., 69: 2074-82, 2010.

7- TOMITTO P., ANNESE V., D'AGOSTINIS, et al.: General \& specific factors associated with severity of cognitive impairement in systemic lupus erythematosus, Arthritis Rheum., 75: 1461-72, 2007.

8- DENBURG S., SUSAND., KATHERNE E., et al.: "How Soft are Soft Neurological Signs ? The relationship of subjective neuropsychatric complaints to cognitive function in systemic lupus erythematosus". J. Rheumatol., 30: 1006-10, 2003.

9- TOMADER ABD EL-RAHMAN and MAHA EL-GAAFARY.: Montreal Cognitive Assessment Arabic version: Reliability and validity prevalence of mild cognitive impairment among elderly attending geriatric clubs in Cairo. Geriatr. Gerontol. Int., 9: 54-61, 2009.

10- VAN SWIETEN J.C., KOUDSTAAL P.J., VISSER M.C., SCHOUTEN H.J. and VAN GIJN: Interobserver agreement for the assessment of handicap in stroke patients. Stroke, 19 (5), 1988.

11-HAEJEONG, MINYOUNG HER, JONG BAE, KIM S.K. LEE S.W., KIM H.K., KIM D., PARK N., CHUNG W.T., LEE S.Y., CHOE J.Y. and KIM I.J.: Brain MRI in neuropsychiatric lupus: Associations with the 1999 ACR case definitions. Rheumatol. International. Springer Online, 2014.

12- AINIALA H., LOUKKOLA J., PELTOLA J., KORPELA M. and HIETAHARJUA.: The prevalence of neuropsychiatric syndromes in systemic lupus erythematosus. Neurology, 57 (3): 496-500, 2001.

13- HAFEZ N., SOLTAN L. and ABO RAY A.A.: Study of Neuropsychiatric Manifestations and Immunological Markers in Systemic Lupus Erythematosus Egypt J. Neurol. Psychiat. Neurosurg., 44 (1): 333-43, 2007.

14- APPENZELLER S., RONDINA J.M., LI LM, COSTALLAT L.T. and CENDES F.: Cerebral and corpus callosum atrophy in systemic lupus erythematosus. Arthritis Rheum., 52 (9): 2783-9, 2005. 
15- SIBBITT W.L. Jr, BRANDT Jr, JOHNSON C.R., MALDONADO M.E., PATEL S.R., FORD C.C., BANKHURST A.D. and BROOKS: The incidence and prevalence of neuropsychiatric syndromes in pediatric onset systemic lupus erythematosus. J.Rheumatol., 29 (7): 153642, 2002.

16- FOERING K., CHANG A.Y., PIETTE E.W., CUCCHIARA A., OKAWA J. and WERTH V.P.: Characterization of clinical photosensitivity in cutaneous lupus erythematosus. J. Am. Acad. Dermatol., 69 (2): 205-13, 2013.

17- EMAN KHEDR, TAYSEER KHEDR, HASSAN FARWEEZ, ABDELLA G. and EL-BEIH E.: Multimodal ElectroneurophysiologicalStudies of SystemicLupus erythematosus. Neuropsychobiology, 43: 204-12, 2001.

18- AFELTRA A., GARZIA P., MITTERHOFER A.P., VADACCA M., GALLUZZO S., DEL PORTO F., FINAMORE L., PASCUCCI S., GASPARINI M., LAGANÀ B., CACCAVO D. and FERRI G.M.: Neuropsychiatric lupus syndromes: Relationship with antiphospholipid antibodies. Neurology, 61 (1): 108-10, 2003.

19- ZHOU H.Q., ZHANG F.C.,TIAN X.P., LENG X.M., LU J.J., ZHAO Y., TANG F.L., ZHANG X., ZENG X.F., ZHANG Z.L., ZHANG W. and DONG Y.: Clinical features and outcome of neuropsychiatric lupus in Chinese: Analysis of 240 hospitalized patients. Lupus, 17 (2): 93-9, 2008.

20- FLOWER C., HAMBLETON I., CORBIN D. and DRIEHUYS B.: Electron microscopic observations of Rb particles and pitting in 129Xe spin-exchange optical pumping Cells. J. Appl. Phys. Jul., 14, 122 (2): 024902.

21- STOVENER LJ, HAGEN K., JENSEN R., KATSARAVA Z., LIPTON R., SCHER A., STEINER T. and ZWART J.A.: The global burden of headache: A documentation of headache prevalence and disability worldwide. Cephalalgia. Mar., 27 (3): 193-210, 2007.

22- WANG X., XING Y., SUN J., ZHOU H., YU H., ZHAO Y. and YAN S.: Prevalence, Associated Factors, and Impact on Quality of Life of Migraine in a Community in Northeast China. J. Oral. Facial. Pain. Headache. Spring, 30 (2): 139-49, 2016.

23- CHIEWTHANAKUL P., SAWANYAWISUTH K. and FOOCHAROE TIAMKAOSN C.: Clinical features and predictive factors in neuropsychiatric lupus. Asian. Pac. J. Allergy. Immunol. Mar., 30 (1): 55-60, 2012.
24- AMAL ABDEL-SATTAR, TAREK GODA and MOHAMED NEGM: Neuropsychiatric manifestations in a consecutive cohort of systemic lupus erythematosus; a single center study International Journal of Rheumatic Diseases, 16: 715-723, 2013.

25- R.L. BREY, S.L. HOLLIDAY, A.R. SAKLAD, NAVARRETE M.G., HERMOSILLO-ROMO D., STALLWORTH C.L., VALDEZ C.R., ESCALANTE A., DEL RINCÓN I., GRONSETH G., RHINE C.B., PADILLA P. and McGLASSON D.: Neuropsychiatric syndromesin lupusPrevalence using standardized definitions. Neurology, 58: 1214-20, 2002.

26- MOK C.C., TO C.H. and MAK A.: Neuropsychiatric damage in Southern Chinese patients with systemic lupus erythematosus. Medicine (Baltimore), 85 (4): 221-8, 2006.

27- SCHENATTO C.B., XAVIER R.M., BREDEMEIER M,PORTELA L.V., TORT A.B., DEDAVID E. SILVA T.L. and SOUZA D.O.: Raised serum S100B protein levels in neuropsychiatric lupus, Ann. Rheum. Dis. Jun., 65 (6): 829-31, 2006.

28- YU H.H., LEE J.H., WANG L.C. and CHIANG B.L.: Neuropsychiatricmanifestations in pediatric systemic lupus erythematosus: a20-year study. Lupus, 15 (10): 651-7, 2006.

29- ABDEL-NASSER A.M., GHALEB R.M., MAHMOUD J.A., KHAIRY W. and MAHMOUD R.M.: Association of anti-ribosomal P protein antibodieswith neuropsychiatric and other manifestations of systemic lupuserythematosus. Clin. Rheumatol., 27: 1377-85, 2008.

30- GÓRA M.K., DOBRZYN'SKA L. and MIERZEJEWSKA E.: EEG examination in patients with systemic lupus erythematosus. Wiad. Lek., 56 (5-6): 220-6, 2003.

31- MATSUKAWA Y.1, NISHINARITA S. and HAYAMA T.: Clinical significance of electroencephalograph in patients with systemic lupus erythematosus Ryumachi. Feb., 33 (1):20-8, 1993.

32- OMDAL R., SELSETH B., KLØW NEHUSBY G. and MELLGREN S.I.: Clinical neurological, electrophysiological, and cerebral CT scan findings in systemic lupus erythematosus. Scand. J. Rheumatol., 18 (5): 283-9, 1989.

33- WANG X., XING Y., SUN J., ZHOU H., YU H., ZHAO Y. and YAN S.: Prevalence, Associated Factors, and Impact on Quality of Life of Migraine in a Community in Northeast China. J. Oral. Facial. Pain. Headache. Spring, 30 (2): 139-49, 2016. 


\section{دراسة عصبية لمرضى الذئبة الحمراء}

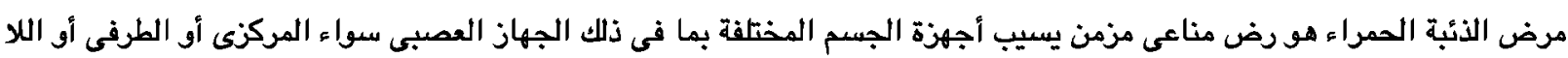

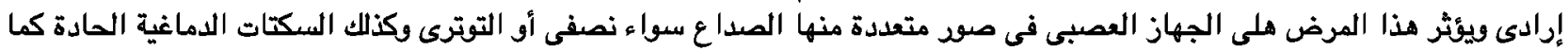

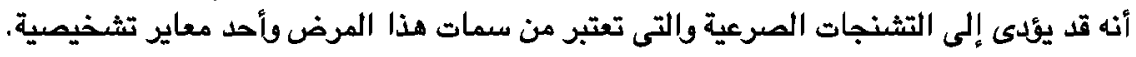

الهدف من الدراسة: دراسة الأعراض العصبية فى مرضى الذئبة الحمراء المتردين على مستشفيات جامعة طنطا خلال ستة أشهر.

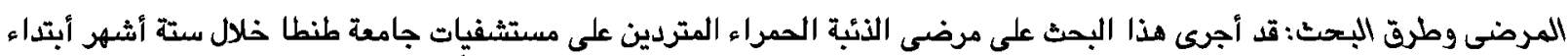

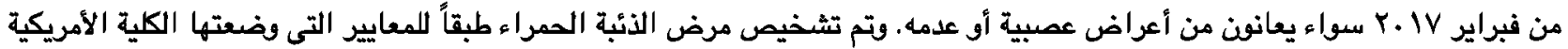

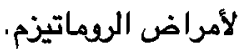

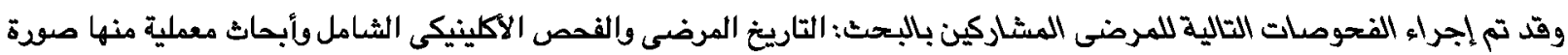

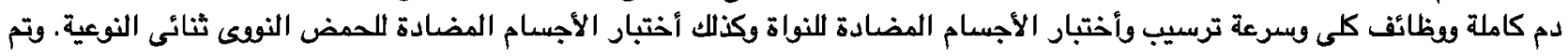

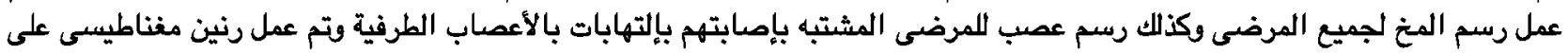

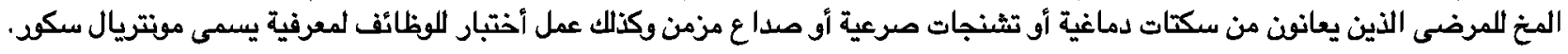

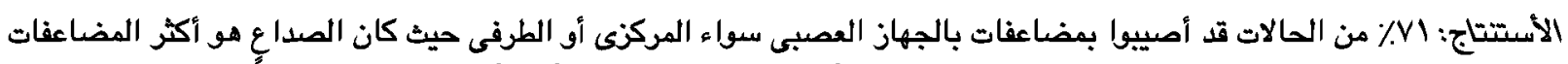

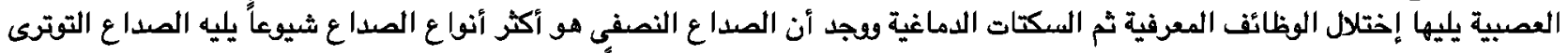

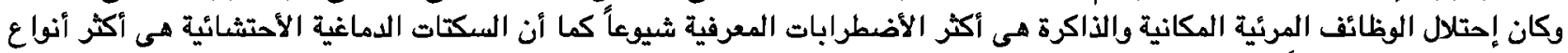
السكتات الدماغية شيولاً. التوصيات: نحن نوصى بضرودة عمل التحاليل اللازمة والتصوير الطبى للاكتشاف المبكر للأعراضالعصبية فى المرضى المصابون بمرض الذئبة العمراءوذالك لأخد العلاج اللازم ومنع تكرار حموثها. 